\title{
Short communication: In vitro and in vivo probiotic potential of Lactobacillus plantarum B7 and Lactobacillus rhamnosus D1 isolated from Minas artisanal cheese
}

\author{
G. L. C. Valente, ${ }^{1 *}$ L. B. Acurcio, ${ }^{2}$ L. P. V. Freitas,,${ }^{1}$ J. R. Nicoli, ${ }^{2}$ A. M. Silva, ${ }^{3}$ M. R. Souza, ${ }^{1}$ \\ and C. F. A. M. Penna ${ }^{1}$ \\ ${ }^{1}$ Departamento de Tecnologia e Inspeção de Produtos de Origem Animal, Escola de Veterinária, Universidade Federal de Minas Gerais, \\ Belo Horizonte, 31270-901, Brazil \\ ${ }^{2}$ Departamento de Microbiologia, Instituto de Ciências Biológicas, Universidade Federal de Minas Gerais, Belo Horizonte, 31270-901, Brazil \\ ${ }^{3}$ Departamento de Engenharia de Alimentos, Universidade Federal de São João del-Rei, Sete Lagoas, 35701-970, Brazil
}

\section{ABSTRACT}

Some Lactobacillus strains may contribute to the health of the host when administered in adequate concentrations, demonstrating their probiotic potential. In contrast, Listeria monocytogenes is a foodborne pathogen that can cause enteropathy, meningoencephalitis, abortion, and septicemia. The aim of this survey was to evaluate the in vitro and in vivo probiotic potential of Lactobacillus plantarum B7 and Lactobacillus rhamnosus D1, isolated from Minas artisanal cheese of the Serra da Canastra (Minas Gerais, Brazil), against Lis. monocytogenes. We submitted B7 and D1 to in vitro testing (antibiogram, tolerance to bile salts and artificial gastric fluid, and spot-on-lawn) and in vivo testing (relative weight gain in mice). Both Lactobacillus strains demonstrated in vitro inhibitory activity against Lis. monocytogenes, as well as sensitivity to antimicrobials and resistance to gastric acids and bile salts. In the in vivo assays, mice treated with D1 gained more weight than mice in the other groups. These results indicate that D1 could have higher probiotic potential than B7 because improvements in feed conversion may help animals fight infection.

Key words: Lactobacillus, probiotics, BALB/c, Listeria monocytogenes

\section{Short Communication}

Some Lactobacillus strains are considered probiotics; that is, they may confer health benefits on their host when administered in adequate amounts (FAO/WHO, 2002). Studies have already shown the capacity of Lactobacillus to improve the condition of digestive and

Received November 2, 2018.

Accepted March 23, 2019.

*Corresponding author: gustlcv.vet@gmail.com genitourinary systems, and to provide anticancer effects and metabolism regulation (Pandey et al., 2015). Among the health benefits of Lactobacillus administration are protection against infectious agents because of nutrient competition, competitive exclusion, direct antagonism, and immuno- and inflammatory modulation (Lebeer et al., 2008).

Listeriosis is a foodborne disease caused by consuming food contaminated with Listeria monocytogenes. This pathogen can be found in animal products, mainly dairy products such as raw milk and cheese (Sonnier et al., 2018). There are 2 types of listeriosis. The noninvasive form is mild: clinical signs include gastroenteritis, fever, vomiting, abdominal pain, and diarrhea. The invasive form is more severe and can cause abortion, meningitis, meningoencephalitis, encephalitis, and septicemia; mortality rates range from 20 to 30\% (Ryser, 2011).

In vitro and in vivo studies have shown that some Lactobacillus strains can inhibit the growth of Lis. monocytogenes. Ortiz-Rivera et al. (2017) observed anti-Listeria effects in meat and dairy products after Lactobacillus inoculation. Lukic et al. (2017) demonstrated the immunomodulatory activity of Lactobacillus in mice, resulting in protection against listeriosis. The inhibition of Lis. monocytogenes has also been observed in other studies evaluating the probiotic potential of lactic acid bacteria isolated from cheeses, including lactobacilli isolated from Minas artisanal cheeses (Costa et al., 2013; Sant'Anna et al., 2017). Acurcio et al. (2017) have also shown that increased weight gain in mice treated with Lactobacillus strains may decrease the severity of infections.

The aim of this study was to evaluate the in vitro and in vivo probiotic potential of 2 Lactobacillus strains against Lis. monocytogenes. The strains used were $L b$. plantarum $\mathrm{B} 7$ and $L b$. rhamnosus $\mathrm{D} 1$, isolated from Minas artisanal cheese produced in Serra da Canastra 
region, Brazil, and identified by Resende et al. (2011); and Lis. monocytogenes ATCC 15313.

The parameters established for evaluation of the in vitro probiotic potential of B7 and D1 were tolerance to bile salts and acidity (Silva et al., 2013), sensitivity to antimicrobials (Charteris et al., 1998), and inhibitory activity against Lis. monocytogenes by spot-onlawn antagonism (Tagg et al., 1976). To establish a comparative pattern, we also tested Lis. monocytogenes against commercial probiotic samples: 6 Lactobacillus casei strains (AC, EL, IT, PA, VI, YA), Lactobacillus paracasei $(\mathrm{CH})$, and Lb. rhamnosus GG (GG; Amara and Shibl, 2015).

For the in vivo assays, we obtained 704 -week-old conventional male BALB/c mice weighing $15-17 \mathrm{~g}$ from the Biotério Central at the Universidade Federal de Minas Gerais (Belo Horizonte, MG, Brazil). The animals were kept in the Laboratório de Ecologia e Fisiologia de Microrganismos (Universidade Federal de Minas Gerais, Belo Horizonte, MG, Brazil) in mini-isolators (ALE. MIL.01.03; Alesco, São Paulo, SP, Brazil) and placed on a ventilated shelf under temperature $\left(22-24^{\circ} \mathrm{C}\right)$ and humidity (60-80\%) control, in a day/night cycle of 12 h. Filtered water and solid food (Nuvilab, Curitiba, PR, Brazil) were offered ad libitum. All procedures in the study were performed following the requirements of Comissão de Ética no Uso de Animais at the Universidade Federal de Minas Gerais (CEUA) under protocol number $80 / 2015$.

We performed a preliminary assay to determine the most suitable doses and route of inoculation to reproduce listeriosis in murine models. We divided the mice into 9 groups of 3 , and each group received an inoculum (whole doses) of Lis. monocytogenes: $100 \mu \mathrm{L}$ by oral gavage at $10^{9}, 10^{8}$, and $10^{7} \mathrm{cfu} ; 100 \mu \mathrm{L}$ intraperitoneally at $10^{7}, 10^{6}$, and $10^{5} \mathrm{cfu}$; or $50 \mu \mathrm{L}$ intravenously at $10^{7}, 10^{6}$, and $10^{5} \mathrm{cfu}$. These values were based on the findings of previous studies (Campion et al., 2013; D'Orazio, 2014; Quereda et al., 2016). All animals were evaluated for $15 \mathrm{~d}$ for mortality, morbidity, and general clinical signs of listeriosis.

Later, we divided a new set of mice into 3 groups of 14; each received the following treatments (whole doses) by gavage each day for $2 \mathrm{wk}$ : $100 \mu \mathrm{L}$ of inoculum of B7 at $10^{8} \mathrm{cfu}, 100 \mu \mathrm{L}$ of inoculum of D1 at $10^{8} \mathrm{cfu}$, or $100 \mu \mathrm{L}$ of $0.9 \%$ saline (control group). On d 11 of treatment, all animals were infected with Lis. monocytogenes, according to the dose and route of inoculation determined in the previous assay $\left(10^{6} \mathrm{cfu}\right.$ intravenously). Throughout the $2 \mathrm{wk}$, the mice were weighed every $48 \mathrm{~h}$.

GraphPad Prism 7.0 software (GraphPad software, San Diego, CA) was used for all statistical analyses. We compared the means of the inhibition halos from spoton-lawn antagonism tests using the Kruskal-Wallis test, followed by a Dunn post-test at a $5 \%$ significance level. In the in vivo studies, we analyzed the relative weight gain results by 2-way ANOVA and compared the findings using a Sidak test at 5\% significance.

Table 1 shows the tolerance of B7 and D1 to bile salts and artificial gastric fluid. Both strains may be classified as tolerant to acid and moderately tolerant to oxgall (Acurcio et al., 2014). Studies of the growth inhibition of lactic acid bacteria isolated from Minas artisanal cheese have shown percentages varying from -24 to $19.68 \%$ with artificial gastric fluid and from -1 to $89.73 \%$ with oxgall (Costa et al., 2013; Sant'Anna et al., 2017). Although B7 and D1 showed moderate tolerance to bile, Ruiz-Moyano et al. (2008) have suggested that resistance could increase when the microorganisms are previously exposed to acid, as occurs in the oral administration of probiotics. According to Lin et al. (2006), some microorganisms tend to express resistance mechanisms when they are previously exposed to sublethal injuries.

The sensitivity pattern of B7 and D1 to antimicrobials is also described in Table 1. The results for both strains resembled those of other studies of the antimicrobial susceptibilities of Lactobacillus strains (Costa et al., 2013; Sant'Anna et al., 2017). Phenotypically, both strains had an appropriate antimicrobial sensitivity pattern, but it would be important to search for resistance genes to more reliably characterize the resistance of B7 and D1 to antimicrobials.

The mean diameters of inhibition halos against Lis. monocytogenes produced by B7, D1, and other probiotic strains Lis.are shown in Figure 1. All lactobacilli were able to inhibit Lis. monocytogenes, and we observed

Table 1. Survival after $12 \mathrm{~h}$ and antimicrobial susceptibility profile of Lactobacillus plantarum B7 and Lactobacillus rhamnosus D1 isolated from Minas artisanal cheese of the Serra da Canastra

\begin{tabular}{lcc}
\hline & \multicolumn{2}{c}{ Lactobacillus strain } \\
\cline { 2 - 3 } Analysis & $\mathrm{B} 7$ & $\mathrm{D} 1$ \\
\hline Survival after $12 \mathrm{~h}(\%)$ & & \\
Bile salts $(0.3 \%$ oxgall $)$ & 57.95 & 46.10 \\
Artificial gastric fluid & 16.65 & 1.06 \\
$\quad(\mathrm{pH}$ 2.0, pepsin 3 g/L) & & \\
Antimicrobial sensitivity & & \\
Ampicilin $(10 \mu \mathrm{g})$ & $\mathrm{S}$ & $\mathrm{S}$ \\
Cefoxitin $(30 \mu \mathrm{g})$ & $\mathrm{R}$ & $\mathrm{R}$ \\
Ceftriaxone $(30 \mu \mathrm{g})$ & $\mathrm{MS}$ & $\mathrm{S}$ \\
Ciprofloxacin $(5 \mu \mathrm{g})$ & $\mathrm{S}$ & $\mathrm{S}$ \\
Chloramphenicol $(30 \mu \mathrm{g})$ & $\mathrm{S}$ & $\mathrm{S}$ \\
Streptomicin $(10 \mu \mathrm{g})$ & $\mathrm{R}$ & $\mathrm{R}$ \\
Gentamicin $(10 \mu \mathrm{g})$ & $\mathrm{R}$ & $\mathrm{R}$ \\
Penicillin $(10 \mu \mathrm{g})$ & $\mathrm{S}$ & $\mathrm{S}$ \\
Tetracycline $(30 \mu \mathrm{g})$ & $\mathrm{S}$ & $\mathrm{S}$ \\
Vancomycin $(30 \mu \mathrm{g})$ & $\mathrm{R}$ & $\mathrm{R}$ \\
\hline
\end{tabular}

${ }^{1} \mathrm{~S}=$ sensitive; $\mathrm{MS}=$ moderately sensitive; $\mathrm{R}=$ resistant. 
no statistical difference between the means inhibition halos of the tested strains (B7 and D1) and the other probiotics. The only significant differences we observed were between probiotic strains: $\mathrm{CH}$ and VI $(P<0.05)$, EL and VI $(P<0.05)$, and GG and EL $(P<0.05)$. Sip et al. (2012) concluded that 284 of $800(35 \%)$ lactic acid bacteria samples isolated from Golka cheese, produced in Poland, inhibited the growth of Lis. monocytogenes. Likewise, $31.9 \%$ of the 699 lactic acid bacteria samples isolated from Sicilian cheeses could interfere with the growth of this pathogen (Macaluso et al., 2016).

In the in vivo experiment, we did not observe clinical signs of listeriosis in mice infected orally or intraperitoneally during the initial $15 \mathrm{~d}$ of observation, regardless of the inoculum concentration. Likewise, mice challenged with $10^{5} \mathrm{cfu}$ of Lis. monocytogenes using an intravenous route did not show any perceptible clinical changes. The resistance of mice to listeriosis can be explained by the weak affinity between host epithelial receptors (E-cadherin and MET) and Lis. monocytogenes surface proteins called internalins, especially InlA and InlB (D'Orazio, 2014). In addition, 90\% of the Lis. monocytogenes cells that reach the bloodstream are removed from circulation and phagocytosed by Kupffer cells in the liver (Llorente and Schnabl, 2016). Becattini et al. (2017) also highlighted the importance of bacteria of the order Clostridiales (present in the intestinal microbiota of mice) in inhibiting the growth of Lis. monocytogenes. The pathogenicity of the Lis. monocytogenes strain may also have hindered the establishment of disease. Liu et al. (2003) demonstrated that after challenging mice intraperitoneally with different strains of this pathogen, Lis. monocytogenes ATCC 15313 had the highest median lethal dose $\left(>1.2 \times 10^{11} \mathrm{cfu}\right)$.

Mice in the groups that received intravenous inoculum with $10^{6}$ and $10^{7}$ cfu of Lis. monocytogenes developed clinical signs that resulted in death in some cases. In the first group, all mice showed clinical signs of listeriosis on d 2 after inoculation. Two mice died the next day, and the surviving mouse showed resolution of clinical signs on $\mathrm{d} 6$. In the second group, 2 mice presented clinical signs of listeriosis $24 \mathrm{~h}$ after infection, leading to death on $\mathrm{d} 2$. The other mouse began to present clinical signs on $\mathrm{d} 2$, resulting in death on $\mathrm{d}$ 3. We observed nonspecific clinical signs such as apathy, anorexia, matted fur, conjunctivitis, and tremors. These findings were consistent with those of Hardy et al. (2015), $4 \mathrm{~d}$ after an intravenous challenge of mice with Lis. monocytogenes $\left(10^{5} \mathrm{cfu}\right)$. Based on the results, we chose an intravenous dose of $10^{6} \mathrm{cfu}$ as our experimental model of infection. Among the treatments tested, it showed the ability to reproduce less intense disease in $\mathrm{BALB} / \mathrm{c}$ mice than the others.

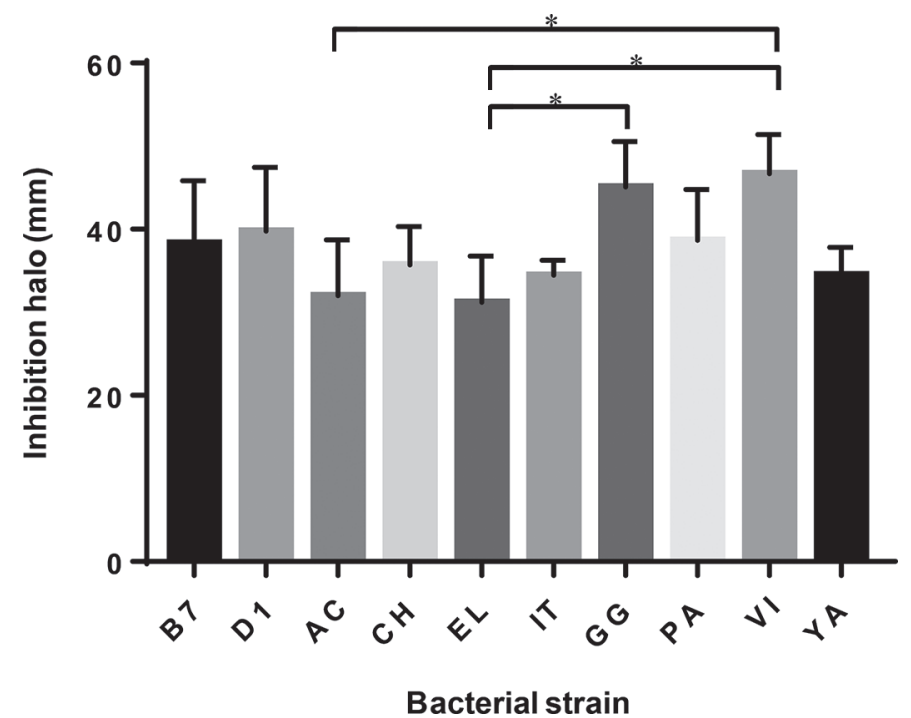

Figure 1. Inhibition halos (mm, mean $\pm \mathrm{SD}$ ) formed by Lactobacillus casei (strains AC, EL, IT, PA, VI, and YA), Lactobacillus paracasei $(\mathrm{CH})$, Lactobacillus rhamnosus (D1 and GG), and Lactobacillus plantarum (B7) against Listeria monocytogenes ATCC 15313 in spot-onthe-lawn test. ${ }^{*} P<0.05$, Kruskal-Wallis test, followed by Dunn's post-test.

The results for the relative weight gain of mice treated with B7, D1, and controls, before and after challenge with Lis. monocytogenes, are shown in Figure 2 . The weight gain observed in animals that received D1 was not connected to the anti-Listeria effect, and was related to a potential probiotic effect that could be exhibited by other lactic acid bacteria. During the pretreatment period, we found no statistical differences between the development of the mice in the control group and the mice in the B7 group. However, after the challenge we found greater weight loss in the mice in the B7 group. Frizzo et al. (2010) observed similar results when treating mice with $L b$. plantarum and challenging them with enteropathogens. According to Million et al. (2012), some strains of Lb. gasseri and Lb. plantarum present an antiobesity effect in the host organism, which results in weight loss. In contrast, the D1 group in our study showed greater weight gain compared with the control group during bacterial administration. The significant difference between the groups remained even after weight loss resulting from inoculation with Lis. monocytogenes. This finding suggests that the administration of D1 can improve physical condition, which may result in greater tolerance of some diseases.

The $L b$. plantarum $\mathrm{B} 7$ and Lb. rhamnosus D1 strains isolated from Minas artisanal cheese produced in the Serra da Canastra region showed resistance to acid and bile salts, antimicrobial sensitivity, and antagonistic effects against Lis. monocytogenes. Both strains had 

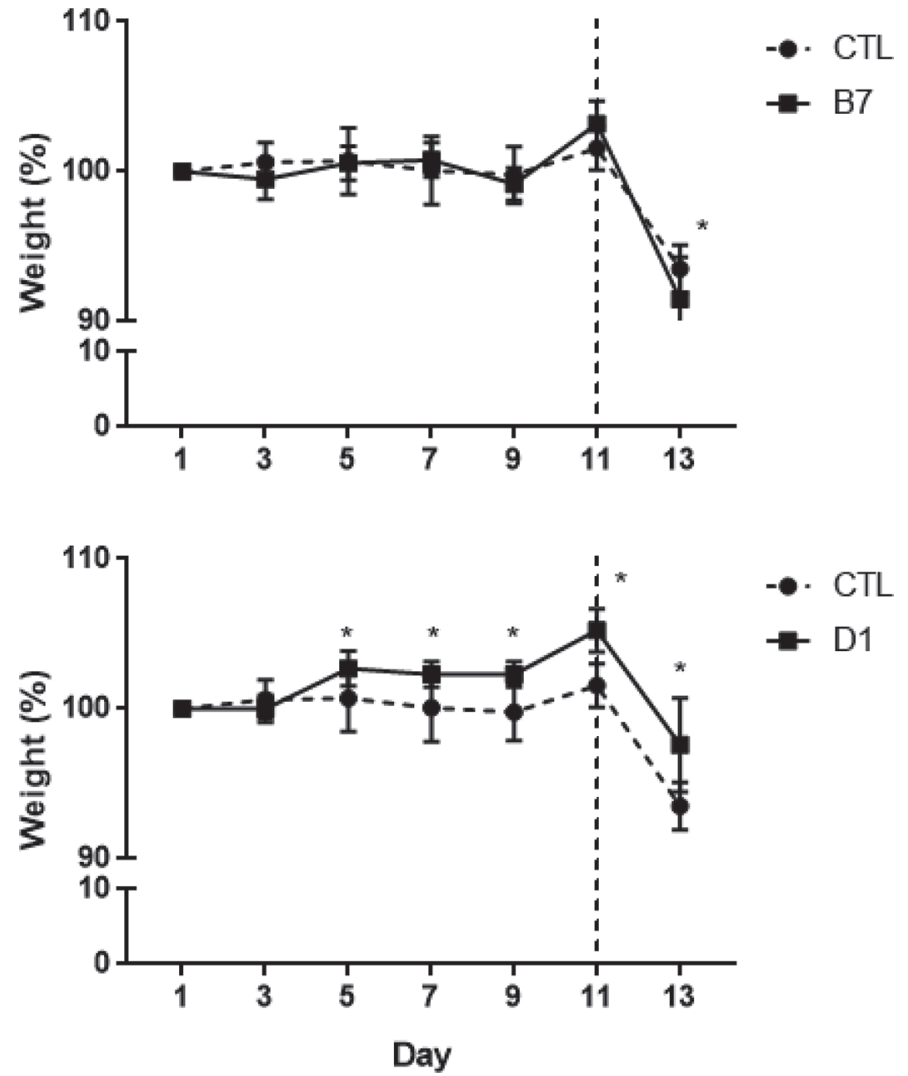

Figure 2. Relative weight gain $(\%)$ of BALB/c mice $(\mathrm{n}=14)$, control (CTL) or treated with Lactobacillus plantarum B7 and Lactobacillus rhamnosus D1 ( $10^{8}$ cfu inoculum orally for $4 \mathrm{wk}$ ) before and after challenge with Listeria monocytogenes ATCC $15313\left(10^{6} \mathrm{cfu}\right.$ inoculum intravenously at d 11). ${ }^{*} P<0.05,2$-way ANOVA, followed by Sidak's post-test. Error bars indicate SD.

satisfactory in vitro probiotic potential and could be tested in future in vivo assays. The mice in the D1treated group showed greater weight gain during pretreatment and after the Lis. monocytogenes challenge. Therefore, Lb. rhamnosus D1 may be the most interesting microorganism for use as a probiotic because of its performance in in vivo and in vitro tests.

\section{ACKNOWLEDGMENTS}

The authors thank the Fundação de Amparo à Pesquisa de Minas Gerais (FAPEMIG), Coordenação de Aperfeiçoamento de Pessoal de Nível Superior (CAPES) and Conselho Nacional de Desenvolvimento Tecnologico $(\mathrm{CNPq})$ for financial support.

\section{REFERENCES}

Acurcio, L. B., S. H. C. Sandes, R. W. Bastos, F. M. Sant'Anna, S. H. S. P. Pedroso, D. C. Reis, A. C. Nunes, G. D. Cassali, M. R. Souza, and J. R. Nicoli. 2017. Milk fermented by Lactobacillus spe- cies from Brazilian artisanal cheese protect germ-free-mice against Salmonella Typhimurium infection. Benef. Microbes 8:579-588.

Acurcio, L. B., M. R. Souza, A. C. Nunes, D. L. S. Oliveira, S. H. C Sandes, and L. B. Alvim. 2014. Isolation, enumeration, molecular identification and probiotic potential evaluation of lactic acid bacteria isolated from sheep milk. Arq. Bras. Med. Vet. Zootec. 66:940-948.

Amara, A. A., and A. Shibl. 2015. Role of probiotics in health improvement, infection control and disease treatment and management. Saudi Pharm. J. 23:107-114.

Becattini, S., E. R. Littmann, R. A. Carter, S. G. Kim, S. M. Morjaria, L. Ling, Y. Gyaltshen, E. Fontana, Y. Yaur, I. M. Leiner, and E. G. Pamer. 2017. Commensal microbes provide first line defense against Listeria monocytogenes infection. J. Exp. Med. 214:1973-1989.

Campion, A., P. G. Casey, D. Field, P. D. Cotter, C. Hill, and R. P. Ross. 2013. In vivo activity of nisin A and nisin V against Listeria monocytogenes in mice. BMC Microbiol. 13:23

Charteris, W. P., P. M. Kelly, L. Morelli, and J. K. Collins. 1998. Antibiotic susceptibility of potentially probiotic Lactobacillus species. J. Food Prot. 61:1636-1643.

Costa, H. H. S., M. R. Souza, L. B. Acurcio, A. F. Cunha, M. F. S. Resende, and A. C. Nunes. 2013. Potencial probiótico in vitro de bactérias ácido-láticas isoladas de queijo Minas artesanal da Serra da Canastra, MG [Probiotic potential of lactic acid bacteria isolated from Minas artisanal cheese from Serra da Canastra, MG]. Arq. Bras. Med. Vet. Zootec. 65:1858-1866. [In Portuguese; English abstract]

D'Orazio, S. E. 2014. Animal models for oral transmission of Listeria monocytogenes. Front. Cell. Infect. Microbiol. 4:15.

FAO/WHO. 2002. Guidelines for the evaluation of probiotics in food. Report of a joint $\mathrm{FAO} / \mathrm{WHO}$ working group on drafting guidelines for the evaluation of probiotics in food, London Ontario, Canada April 30 and May 1, 2002. Food and Agriculture Organization of the United Nations (FAO), Rome, Italy; World Health Organization (WHO), Geneva, Switzerland.

Frizzo, L. S., M. V. Zbrun, L. P. Soto, E. Bertozzi, M. L. Signorini, G. J. Sequeira, L. E. Marti, R. D. Santinam, G. Perdigon, and M. R. Rosmini. 2010. Protective effect of an inoculum of lactic acid bacteria from bovine origin against Salmonella serotype Dublin in the intestinal tract of mice. J. Anim. Vet. Adv. 9:2113-2122.

Hardy, J. W., Z. Levashova, T. L. Schmidt, C. H. Contag, and F. G. Blankenberg. 2015. $\left.{ }^{99 \mathrm{~m}} \mathrm{Tc}\right]$ annexin V-128 SPECT monitoring of splenic and disseminated listeriosis in mice: a model of imaging sepsis. Mol. Imaging Biol. 17:345-354.

Lebeer, S., J. Vanderleyden, and S. C. J. Keersmaecker. 2008. Genes and molecules of lactobacilli supporting probiotic action. Microbiol. Mol. Biol. Rev. 72:728-764.

Lin, W. H., C. F. Hwang, L. W. Chen, and H. Y. Tsen. 2006. Viable counts characteristic evaluation for commercial lactic acid bacteria products. Food Microbiol. 23:74-81.

Liu, D., A. J. Ainsworth, F. W. Austin, and M. L. Lawrence. 2003 Characterization of virulent and avirulent Listeria monocytogenes strains by PCR amplification of putative transcriptional regulator and internalin genes. J. Med. Microbiol. 52:1065-1070.

Llorente. C., and B. Schnabl. 2016. Fast-track clearance of bacteria from the liver. Cell Host Microbe 20:1-2.

Lukic, J., I. Jancic, N. Mirkovic, B. Bufan, J. Djokic, M. Milenkovic, J. Begovic, I. Strahinic, and J. Lozo. 2017. Lactococcus lactis and Lactobacillus salivarius differently modulate early immunological response of Wistar rats co-administered with Listeria monocytogenes. Benef. Microbes 8:809-822.

Macaluso, G., G. Fiorenza, R. Gaglio, I. Mancuso, and M. L. Scatassa. 2016. In vitro evaluation of bacteriocin-like inhibitory substances produced by lactic acid bacteria isolated during traditional Sicilian cheese making. Ital. J. Food Saf. 5:5503.

Million, M., E. Angelakis, M. Paul, F. Armougom, L. Leibovici, and D. Raoult. 2012. Comparative meta-analysis of the effect of Lactobacillus species on weight gain in humans and animals. Microb. Pathog. 53:100-108. 
Ortiz-Rivera, Y., R. Sánchez-Vega, N. Gutiérrez-Méndez, J. LeónFélix, C. Acosta-Muñiz, and D. R. Sepulveda. 2017. Production of reuterin in a fermented milk product by Lactobacillus reuteri: Inhibition of pathogens, spoilage microorganisms, and lactic acid bacteria. J. Dairy Sci. 100:4258-4268.

Pandey, K. R., S. R. Naik, and B. V. Vakil. 2015. Probiotics, prebiotics and synbiotics - A review. J. Food Sci. Technol. 52:7577-7587.

Quereda, J. J., O. Dussurget, M. A. Nahori, A. Ghozlane, S. Volant, M. A. Dillies, B. Regnaul, S. Kennedy, S. Mondot, B. Villoing, P. Cossart, and J. Pizarro-Cerda. 2016. Bacteriocin from epidemic Listeria strains alters the host intestinal microbiota to favor infection. Proc. Natl. Acad. Sci. USA 113:5706-5711.

Resende, M. F. S., H. H. S. Costa, E. H. P. Andrade, L. B. Acurcio, A. F. Drummond, A. F. Cunha, A. C. Nunes, J. L. S. Moreira, C. F. A. M. Penna, and M. R. Souza. 2011. Queijo-de-Minas artesanal da Serra da Canastra: influência da altitude das queijarias nas populações de bactérias ácido-lácticas. [Influence of altitude on lactic acid bacteria population of Minas artisanal cheese from Serra da Canastra]. Arq. Bras. Med. Vet. Zootec. 63:1532-1538. [In Portuguese: English abstract]

Ruiz-Moyano, S., A. Martín, M. J. Benito, F. P. Nevado, and M. Guía Córdoba. 2008. Screening of lactic acid bacteria and bifidobacteria for potential probiotic use in Iberian dry fermented sausages. Meat Sci. 80:715-721.
Ryser, E. T. 2011. Pathogens in milk: Listeria monocytogenes. Pages 1650-1655 in Encyclopedia of Dairy Science. 2nd ed. H. Roginski, P. F. Fox, and J. W. Fuquay ed. Academic Press, London, UK.

Sant'Anna, F. M., L. B. Acurcio, L. B. Alvim, R. D. Castro, L. G. Oliveira, A. M. Silva, A. C. Nunes, J. R. Nicoli, and M. R. Souza. 2017. Assessment of the probiotic potential of lactic acid bacteria isolated from Minas artisanal cheese produced in the Campo das Vertentes region, Brazil. Int. J. Dairy Technol. 70:592-601.

Silva, B. C., L. C. R. Jung, S. H. C. Sandes, L. B. Alvim, M. R. Q. Bomfim, J. R. Nicoli, E. Neumann, and A. C. Nunes. 2013. In vitro assessment of functional properties of lactic acid bacteria isolated from faecal microbiota of healthy dogs for potential use as probiotics. Benef. Microbes 4:267-275.

Sip, A., M. Więckowicz, A. Olejnik-Schmidt, and W. Grajek. 2012. Anti-Listeria activity of lactic acid bacteria isolated from golka, a regional cheese produced in Poland. Food Control 26:117-124.

Sonnier, J. L., J. S. Karns, J. E. Lombard, C. A. Kopral, B. J. Haley, S. W. Kim, and J. A. S. Van Kessel. 2018. Prevalence of Salmonella enterica, Listeria monocytogenes, and pathogenic Escherichia coli in bulk tank milk and milk filters from US dairy operations in the National Animal Health Monitoring System Dairy 2014 Study. J. Dairy Sci. 101:1943-1956.

Tagg, J. R., A. S. Dajani, and L. W. Wannamaker. 1976. Bacteriocins of Gram-positive bacteria. Bacteriol. Rev. 40:722-756. 